\title{
Canada's Model Forest Program: Challenges for Phase II $^{\mathbf{1}}$
}

\author{
by Rod Carrow ${ }^{2}$
}

\section{Introduction}

I would like to begin by reflecting back to the 1980 s, and the events of that decade. These events were significant because they provided much of the stimulus for the 1992 National Forest Strategy and the concept of model forests. It was at this time that Forestry Canada commissioned the first national survey of public opinion on forestry (Forestry Canada 1989). The survey yielded a variety of views, many surprising. Among them:

- $\quad 75 \%$ of Canadians viewed our forests as a national treasure held in trust for future generations;

- $50 \%$ believed that the most important use of our forests was wildlife protection and wilderness;

- $70 \%$ disapproved of clearcut harvesting and the use of chemicals in the forest; and

- only $20 \%$ believed that the forest industry had a promising future.

This was the environment of public opinion which spawned a series of conflicts over forest management and forest practices - Temagami in northern Ontario; South Moresby Island in the Queen Charlottes; the Carmanah Valley and Clayoquot Sound on Vancouver Island, and most recently the Christmas Mountains in New Brunswick. Interwoven through many of these local conflicts was a more fundamental and widespread challenge, that of aboriginal land claims from coast to coast. And of course, forestry conflicts are not a Canadian phenomenon. In the US Pacific Northwest, protection of the spotted owl led to unprecedented hostility and conflict between naturalists and loggers, and eventually to substantial reductions in timber supply and loss of jobs. And half way around the world, the government of New Zealand disbanded its national forest service in 1985 , because it had been unable to adapt its forest management to the changing priorities of New Zealanders.

This period of conflict has continued throughout the 1990s despite attempts by governments and industry to address and improve many of the specific criticisms of Canadian forestry. Our response has been to deal with each conflict or criticism in isolation by doing such things as:

- $\quad$ setting aside more of the productive forest land base as protected forest;

- modifying our clearcutting practices so that the size and shape of the blocks are more controlled

- developing new types of harvesting systems that allow us to harvest more selectively, and with less site damage;

- replacing many chemical pesticides with biological products;

\footnotetext{
${ }^{1}$ Paper presented at "People Growing with the Forests," Model Forest Program Conference, Winnipeg, Manitoba, May 12B15, 1997.

${ }^{2}$ Professor and Dean Emeritus, Faculty of Forestry, University of Toronto. R.R. 5, Orangeville, Ontario L9W 2 Z2.
}

- $\quad$ substantially increasing our research effort on non-timber values such as wildlife, biodiversity, old growth forests, and community futures; and

- incorporating wildlife habitat supply into forest management planning.

But perhaps the one area of criticism that has occupied us more than any other is that of

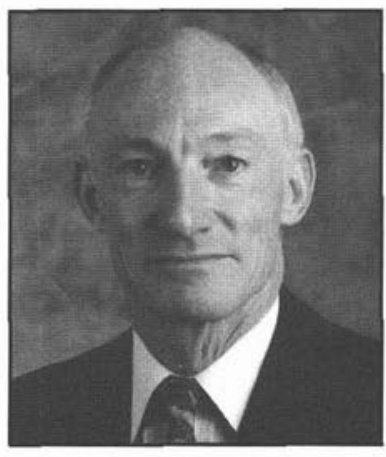
public participation in forest management. Certainly it has occupied us the longest. Historically, the direction and priorities in forest management on Crown land were determined through negotiation and discussion between the provincial government and the forest industry. This process prevailed, largely undisturbed, until the 1960 s when the first wave of environmentalism was born. Organizations like Greenpeace, Pollution Probe and the Sierra Club attracted public attention by challenging specific programs and practices, including forestry, and it was through these initiatives that the public first developed an awareness and some understanding that there were indeed environmental consequences to economic development. In many situations, the voice of the environmental critic was the lone voice of the public, because historically, the public had been generally disinterested and apathetic.

Three decades ago, the initial stages of public participation in forestry and forest management were marked by hostile confrontations, civil disobedience, and acrimonious discussion. However, as we moved forward from the 1960s, this form of public participation was gradually replaced with advisory boards or committees which allowed for systematic input into planning and management. As well, many agencies introduced the concept of the public "open house," discussion documents and comment periods which provided an opportunity for the non-organized public to participate. This advisory role prevailed throughout the 1970 s and much of the 1980 s, but as time passed, the involved public became increasingly disenchanted with this role, largely because in many cases (but not all), public advice had little influence on forest policy or management.

Then in 1987, with the publication of the Brundtland Commission Report, Our Common Future (World Commission on Environment and Development 1987), a new model of public participation, the Round Table, emerged. This was indeed a landmark because the Round Tables established a new style of public involvement, with attributes such as:

- openness and inclusiveness,

- consensus in decision-making, and

- multi-stakeholder participation.

It was not long before the potential of the Round Table to reach informed, rational decisions became apparent, and about the same time, the concept of devolution of responsibility and local empowerment began to attract support. So in 
the space of three decades, public involvement gradually took different forms, starting with a period of open hostility and antagonism, to discussion, to an advisory role, and presently relying more on consensus-building and to some degree local empowerment.

Other changes in the forestry sector also characterized the 1980s. This was the period when local wood shortages started to become a reality rather than a topic of academic debate, and a national awareness of serious shortfalls in timber supply in the early part of the next century developed. In response, we did what we could in the short term - dramatically increase planting and tending programs, and improve our capability in timber supply planning and forest protection. During this decade also, terms such as forest ecosystem, wildlife habitat, non-timber values and integrated resource management appeared in forest legislation, policies and forest management manuals, as the concepts of multiple use and integrated use management became more accepted.

So the decade of the 1980s was one of great change in forest policy, especially in public participation, timber supply, forest regeneration and the recognition of multiple values in the forest. This was the environment which gave rise to the 1987 National Forest Sector Strategy for Canada, and five years later the 1992 National Forest Strategy, Sustainable Forests: a Canadian Commitment was spawned. Only five years had passed between these two important statements of national forestry priorities, but what a difference in the content and the language! First, the 1987 Strategy was developed by a Task Force whose 14 members included only one person who was not directly associated with the forestry sector; that person represented the Canadian Wildlife Federation. In contrast, the 1992 Strategy was developed through broad national public consultation, and ratified by 27 signatories who represented not only the traditional forestry constituency, but also the aboriginal community, naturalist organizations, wildlife associations and private woodlot owners. The more comprehensive and open process of consultation which produced the 1992 document led to a much stronger Strategy, and one which reflected more accurately changing public opinion about our forests.

For example, on the topic of public participation, the 1987 strategy makes only brief reference under the heading "Concerning Public Awareness." The lead recommendation reads: "It is recommended that all segments of the forest sector continue and enhance national, regional and local programs to assist the public to understand the forest and seek their cooperation in its wise use and management." In hindsight, this was a patronizing position that assumes that everything we were doing in the forest was fine, it's just that the public didn't understand it! Public participation is one of the 9 strategic directions in the 1992 strategy, and there are 11 specific commitments to action related to public participation. The first commitment speaks of involving the public in developing and reviewing forest policies, preparing forest land use plans, developing forest management plans and resolving conflict.

Related to those commitments is another one which is of special interest to this conference. It is contained within Strategic Direction Two: Forest Management Practices. It reads:

"By 1994, members of the forest community will cooperate to establish working models of sustainable forest management in the major forest regions of Canada. These models will be:

- based on the management of forest ecosystems;
- managed to achieve a full range of forest values;

- open to public participation within a consultative framework; and

- capable of demonstrating and evaluating new and ecologically sound forest practices."

Of course, this is the commitment which led to the Model Forest program. I believe it was a brilliant commitment, one in which the signatories to the Strategy should take great pride, one for which the Canadian Forest Service should be highly commended for its prompt initiation, and one for which the many partners in the program should take great credit.

\section{The Model Forest Program: Phase I}

The first phase of the Model Forest Program, initiated in 1992, had as its goal to "shift the management of Canada's forests from sustained yield to sustainable development." This goal was a positive ambiguity - sufficiently ambiguous as to allow each Model Forest considerable latitude in developing its own recipe for sustainable forestry, but positive in that it clearly intended to stimulate a positive shift towards sustainability. The objectives were somewhat more precise:

- to accelerate the implementation of sustainable development in the practice of forestry, particularly the concept of integrated resource management;

- to apply new and innovative approaches, procedures, techniques and concepts in the management of forests, and

- to test and demonstrate best sustainable forestry practices utilizing the most advanced technology and forestry practices available.

Bearing in mind the environment within which the Model Forest program was conceived, and especially the legacy of public conflict which it inherited, the accomplishments of Phase I were impressive and significant. The program evaluation done in 1996 revealed several major achievements:

1. The program has indeed accelerated the introduction of sustainable forestry by at least five years, by acting as a catalyst to expedite the shift towards sustainability.

2. The effectiveness of the new partnerships that have been created should be regarded as a major accomplishment, one that was not entirely anticipated at the outset, but one that became possible because of the novelty and neutrality of the program.

3. In many cases, the structure of the partnership and the process for decision-making provided the forum for several new forest values and perspectives, along with the historic timber supply interests.

4. The involvement of the First Nations in six of the ten Model Forests represents an important step forward - one which is absolutely essential if we are ever to move beyond the conflict over aboriginal rights and natural resources which has been so common in the past quarter century.

5. Research on a range of important social, economic, cultural and ecological topics has contributed substantially to our understanding of the diverse elements that constitute sustainable forestry.

The same evaluation revealed a number of deficiencies in the program, but before discussing these, I want to emphasize that five years in the life of a forest and in the life of such a novel program is indeed very short, and we should be realistic about what can be achieved in such a short time.

1. Generally, there has been little evidence of change on the 
ground, or of forest companies transferring knowledge from the program to other parts of their operations. As one person said: "the clear cut blocks still look the same as they did five years ago."

2. The Model Forests have tended to be inward looking, with the result that too little of the information and knowledge generated by the program has been communicated to organizations and people outside the program.

3. There has been little if any influence of the program on provincial forest policy, and indeed, the commitment of the provincial agencies to the program has been variable and modest. This is a very important factor, because if the program is to promote change on the ground, it will have to happen through changes in provincial forest policies, guidelines, standards and management manuals.

4. Generally, the process used to solicit, review and evaluate research proposals needs to be more systematic, and carried out within the context of the research needs of each Model Forest.

Nevertheless, Phase I of the Model Forest Program has shown the value of a non-traditional approach to forest management which involves all organizations with an interest in our forests, and has as its goal a shift from management for sustained timber yield to management for multiple forest values.

\section{The Model Forest Program: Phase II}

As Phase I of the program was proceeding through the 1990s, it was doing so in the midst of a period of change that was unprecedented in the past 50 years. In fact, the most likely reason the Model Forest program had so little influence on forest policy in Canada is that the program was simply overtaken, and overwhelmed by the substantial changes in trade, government programs and regulation.

In his book, The End of Work, Jeremy Rifkin (1995) gives a comprehensive historical account of technological change and productivity improvements in western society, and argues that the future for traditional employment and jobs is bleak. However, he sees the emergence of what he calls the "Third Sector," community-based, non-government organizations as a hopeful alternative to the market sector and the public sector.

A few quotes illustrate his thesis:

"In the coming century, the market and public sectors are going to play an ever-reduced role in the day-to-day lives of human beings around the world." (p. 249)

"The globalization of the market sector and the diminishing role of the governmental sector will mean that people will be forced to organize into communities of selfinterest to secure their own futures." (p. 250)

"Only by building strong self-sustaining local communities will people in every country be able to withstand the forces of technological displacement and market globalization that are threatening the livelihood and survival of much of the human family." (p. 250)

Do these observations ring a bell for those of you involved in the Model Forest program? They certainly should! And right here in Manitoba, we have the "community of self-interest" that has formed to take on the responsibility for the mill at Pine Falls.

Rifkin sees the role of government changing from one that is tied to the interests of the commercial economy to one that is more aligned with the interests of the social economy, one that results in a partnership between the government and the Third Sector.

I believe many of the events of the 1990s lend credence to Rifkin's arguments. We see more and more evidence of people losing confidence in the ability of both government and the business sector to provide opportunities for secure economic futures. In Canada's forestry sector alone, we have seen:

- substantial government down-sizing and off-loading of programs to local governments and the community;

- the development of a variety of models for communitybased governance and management;

- new business arrangements between the provincial governments and the forest industry;

- a steady stream of international corporate mergers involving Canadian companies that historically were the linchpins of our forest sector;

- $\quad$ trade barriers and protectionism against Canada's forest industry; and

- the appearance of new and more restrictive regulations on forest practices, such as the Class Environmental Assessment in Ontario, the Forest Practices Code in B.C. and certification systems for sustainable forest management.

Just as the Phase I Model Forest program grew out of an era characterized by public conflict, a growing concern about future timber supplies and a recognition of the multiple values of forests, Phase II is starting in quite a different socio-political environment, one in which the role of governments in a whole range of programs, including forest management will likely continue to recede. It is also a period when Canada's forest industry will likely find it increasingly difficult to remain globally competitive, given the host of new restrictions, new responsibilities and new costs being imposed on them by the provincial governments.

All of this is to simply illustrate that the Model Forest program does not operate in isolation; it operates within the context of a constantly changing Canadian forestry sector, and a constantly changing socio-political environment, both nationally and globally. The program must stay connected to and aware of this dynamic, because it is by being connected that it will have the greatest chance to truly influence future policy and management to achieve sustainable forestry - to get that "change on the ground" we all desire.

The goals and objectives for Phase II of the program include:

- developing world class leadership in the implementation of sustainable forest management in Canada;

- demonstrating the practical application of sustainable forest management systems;

- establishing indicators of sustainable forest management, along with systems for monitoring, measuring and reporting performance, and

- incorporation of a broad range of forest values into each Model Forest.

\section{Challenges For Phase II}

If I have the opportunity to be involved in the evaluation of Phase II in five years, I would like to be able to report that the program has made very substantial advances in all these areas - advances that would surely position Canada as a world leader in demonstrating what sustainable forest management is on the ground. Today I would like to leave you with three 


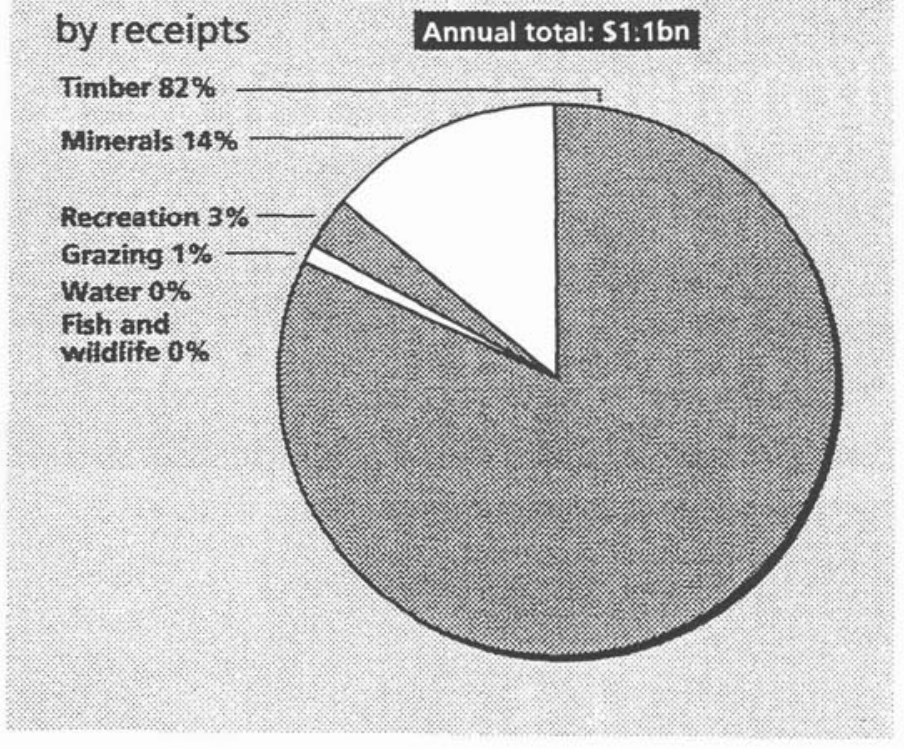

\section{by potential value Annual total: $\$ 3.4 \mathrm{bn}$}

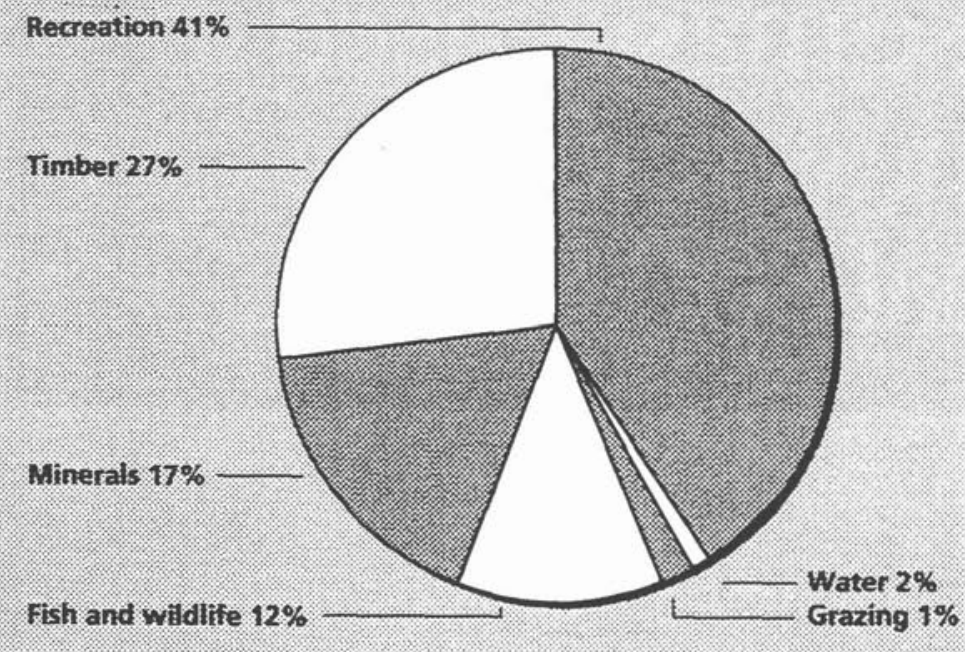

Fig. 1. A Price on Trees, U.S. National Forests (Source: U.S. Forest Service) challenges as you begin Phase II - challenges which I believe will move the Model Forest program to a level of achievement which will address the future needs of Canadians and will gain international respect.

\section{The Integrated Resource Management Licence}

The first challenge is what I will call the Integrated Resource Management Licence - the IRML — as a true alternative to the traditional Forest Management Agreement, Tree Farm Licence, or Sustainable Forest Licence. The challenge I want to present today is for the Model Forest program to demonstrate, as a pilot project, that an IRML is practical, achievable and financially viable within the provincial policy and legislative framework; a further part of the challenge is to show that such a licence is entirely consistent with the criteria for sustainable forest management developed by the Canadian Council of Forest Ministers (CCFM).

The rationale behind such a licence is sound. Our forests have a multiplicity of values. Some are exploitable; many are not. Some values are as yet undiscovered. Some of our forest values are priced in response to market forces; some are arbitrarily priced by governments with little attention to market value; some values are unpriced. For too long in Canada, we have clung to the belief that the only real sustainable economic value in our public forests was commercial timber, and that every other asset was of low value. If we looked beyond our borders, if we paid attention to changing social priorities in the world, we would realize that the values in Canada's forest environment are diverse, numerous, some obvious and some subtle, and many are rare. We would also realize that many 
forest values that we previously considered insignificant or "unpriceable" are attaining market value in response to growing public demand and interest.

This view was reflected in a 1991 article in the Economist, which says:

"As people grow richer, they prize - and will pay for

- the recreation they can find in woodland, and the

pleasure they win from the knowledge that they are

preserving nature." (The Economist 1991)

We need to start paying attention to these people. Historically, they have prized and paid for lumber and toilet paper; now they prize and are willing to pay for much more from our forests.

To illustrate the potential and unrealized values in our forests, the U.S. Forest Service recently compared the actual returns and potential returns from various activities on their National Forests (Fig. 1). The analysis shows that in 1991, total annual receipts were $\$ 1.1$ billion, with $82 \%$ from timber, only $3 \%$ from recreation, and zero from fish and wildlife (The Economist 1991). The potential value of activities on the forests was triple the receipts, $\$ 3.4$ billion, with recreation generating $41 \%$ of the revenue, timber $27 \%$ and fish and wildlife $12 \%$.

Closer to home, $\$ 5.6$ billion was spent on wildlife-related activities in Canada in 1991, a 33 \% increase over the previous decade (Environment Canada 1995).

Canada grew up as a hewer of wood and drawer of water; we should continue to hew and to draw, and we should strive to be among the best in the world in these endeavours. We should also recognize that a changed world has presented us with new economic opportunities in the forest which we never would have dreamed of in the past - opportunities for jobs, income, revenue and trade, and much-needed opportunities for our youth, $17 \%$ of whom are unemployed today.

These opportunities could be realized through Integrated Resource Management Licences, which could be established on several Model Forests as five- year pilot projects. Such a licence would assign total responsibility for managing the values within the Model Forest area - timber, recreation, hunting, fishing, and other activities - to one organization, the Model Forest. The licence would operate within the criteria and indicators for sustainable forest management and the provincial legislative framework that provides for forest resource licences.

Two features would distinguish the licence from those with which we are familiar across Canada:

- The responsibility for management of all forest values within the licence area would be assigned to one organization, the licensee. The Model Forest is ideally structured to take on such a responsibility. This is in contrast to existing licences in which responsibility for management is divided between the industrial licensee and the provincial government.

- The licence would operate as a financially independent business, with the opportunity to generate revenue from facilities, services and products and the responsibility of bearing the full costs of operation. Again the structure of the Model Forest as an arms-length organization should allow it to operate easily in this role.

Such a licence would allow the licensee to develop an optimal mix of activities that reflects the potential of the forest area, local and regional priorities, and client demand. If this

\begin{tabular}{lr}
\hline Table 1. Annual visitor-days at Haliburton Forest, 1995/96 \\
\hline Campsite leases & 32000 \\
Daily users and visitors & 12000 \\
Snowmobilers & 14000 \\
Hunters & 5000 \\
Anglers & 1000 \\
Outdoor education & 4000 \\
Wolf Centre & 7000 \\
Hiking, cycling & 4000 \\
Total & 79000 \\
\hline
\end{tabular}

were pursued within the Model Forest program, I would expect that the mix of activities would differ greatly from one Model Forest to another.

What I am describing is not a new concept. Integrated resource management has been studied and described in the literature for decades; some jurisdictions claim to practice a form of IRM. Were it not that our political leaders, senior civil servants and forest industry leaders have been so collectively unimaginative and timid, this model of resource management would have been a reality ten or 20 years ago.

Let me give you one example of imagination and innovation - the Grizedale Forest, managed by the British Forestry Commission in northern England. This working forest is the venue for a studio, where sculptors and artists can come to work for the summer months; the only condition is that the artists must work with materials from the forest. The forest is also the home for a centre of performing arts. These activities attract over 20000 visitors a year to the Forest and they contribute substantially to local small business development, employment and community stability.

Another example is the Haliburton Forest in Ontario, which has operated on the principle of integrated resource management for over 30 years, and is financially viable. The success of this forest lies in the ability of the owner to anticipate and develop activities which attract people to the forest, as well as carry on traditional harvesting operations. Last year, the forest supported 79000 visitor-days of activities campers, snowmobilers, hunters, anglers, cyclists, etc. (Table 1). The distribution of income from these activities is summarized in Fig. 2. The diversity of activity is worth noting. Only ten years ago, income on the forest came from only three sources - logging, campsite leases and snowmobiling. These three activities now generate about $60 \%$ of the revenue, with the remaining $40 \%$ coming from a variety of new activities and programs, much of it outdoor education. It is also worth noting that only $22 \%$ of the revenue comes from timber production.

Through these programs, this forest brings in gross revenues of $\$ 1.2$ to $\$ 1.5$ million annually. As a point of interest, the land base for Haliburton Forest is only 20000 ha. Think what could be accomplished if some of our Model Forests were operated as integrated resource management units!

\section{The Model Forest as a Model for Local Governance}

The second challenge I want to leave with you is to develop the Model Forest organization as a working example of community-based, local governance. This relates back to the continuing demand for better public participation, and I believe that the local, community-based organizations provide the most effective model for public involvement. It would be difficult to over-emphasize the importance of new governance models in our quest for forest sustainability. 


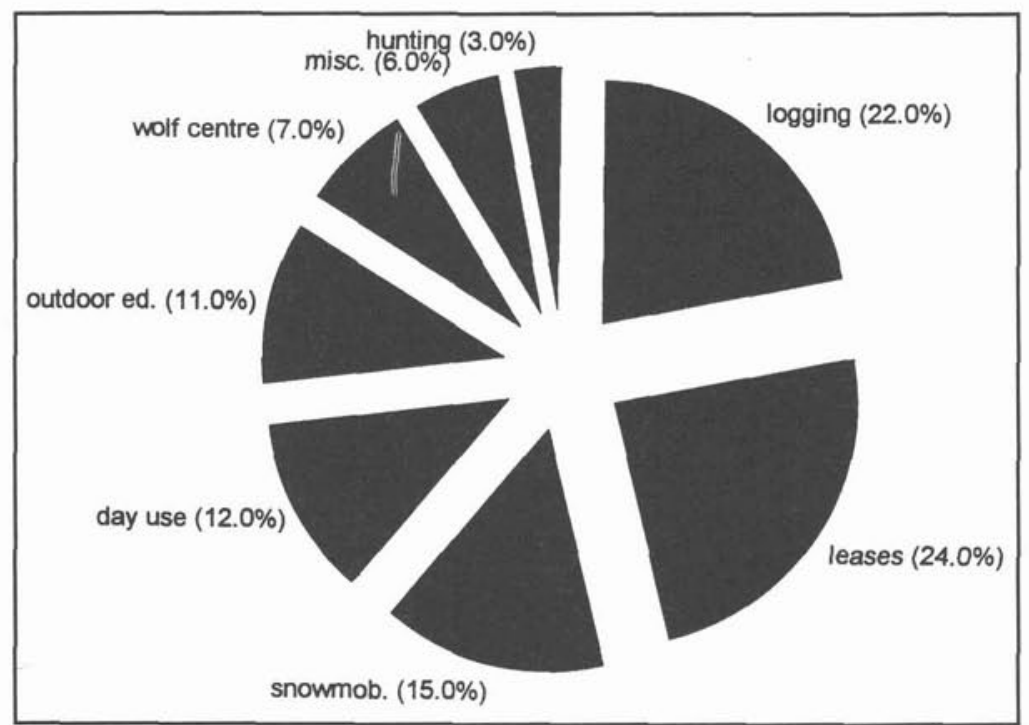

Fig. 2. Haliburton Forest: Distribution of Gross Operating Income, 1996.
For a fundamental principle of sustainable development is a balancing of environmental, social and economic considerations, and to do so effectively requires an organizational structure that can integrate these three elements. To do so also requires an organization that includes all three perspectives in policy setting, planning and management.

Our traditional institutional structures, both in the public and private sectors, make it very difficult, if not impossible, to fully achieve such integration. Indeed, one could argue that the greatest single obstacle to the achievement of sustainable forestry is badly outdated institutional structures and arrangements. Our government departments, our businesses and corporations, even our non-government organizations are generally single interest entities; certainly if they have a focus on economic development, they usually have little interest in social or environmental priorities. Those are seen as the concern of other organizations.

With these institutions, the progress we make towards integration and sustainable forestry is accomplished through conflict, negotiation, concession, regulation and public pressure, not through proactive, innovative planning - hardly a formula for the world class leadership to which we aspire. In fact, the legacies that often accompany these institutions make it very difficult for those groups and individuals with a strong interest in our forests to move beyond the conflict stage into a more constructive and cooperative process of policy formulation and forest management planning.

Of course, other events further complicate the picture. With governments down-sizing and off-loading programs to local governments, the private sector and communities, and with larger companies constantly re-structuring in an effort to remain globally competitive, local communities are being forced to assume new responsibilities. As Rifkin said, we are seeing the emergence of the Third Sector, the ever-increasing community of people who are outside of the public and the market sectors. And as government and the private sector become less effective in meeting the social and economic needs of society, we are being forced to discover new ways of taking more responsibility for our own destiny.
Community-based organizations dedicated to natural resource management are not new in Canada; they have been around in various forms for half a century at least. But in recent years, some different models have emerged, models which progressively assign more responsibility to the organization and result in more local empowerment. The Model Forest organization is one example of these. Phase I demonstrated clearly the value and the potential of an inclusive, community-based approach to forest management in which all of the stakeholders with a serious interest in the forest are at the table. Phase II provides the opportunity to further develop and strengthen the concept of a community-based partnership with responsibility for sustainable forest management.

For such an organization to be effective, there are several attributes which should be incorporated into the design (Carrow 1996). Some of the more important ones are:

- a supportive lead agency. The provincial government must support and facilitate the formation of the organization.

- $\quad$ authority and responsibility. There must be a meaningful transfer of authority and responsibility for management from the provincial government to the organization.

- tenure. The form of tenure granted to the organization should be consistent with the scope of responsibility and authority of the organization, and should be sufficiently long and secure to impart a sense of co-ownership to the organization.

- revenue autonomy. For the organization to become financially independent, it must have the opportunity and authority to generate and retain revenue from all the activities and programs carried out by the organization.

- inclusion of interests. The governing body for the organization, the Board of Directors for example, must ensure that all legitimate interests are included in forest resource planning, with the objective of developing a community consensus on forest values and forest management objectives.

Interestingly, Phase I of the Model Forest program served as a basis for the development of two community-based man- 
agement agencies with whom I have worked. One is the proposed Bras d'Or Stewardship Commission in Nova Scotia which would have responsibility for sustainable development in the Bras d'Or Lakes watershed on Cape Breton Island, and the other is Westwind Forest Stewardship Inc., based in Parry Sound, Ontario. The Bras d'Or Commission is still under consideration by the provincial government, but Westwind has been formed and is now in business, with responsibility for forest management on Crown land in the Parry Sound-Bracebridge district. It is in the process of negotiating a new Sustainable Forest Licence with the province, and the Board of Directors will be in place by June 1st.

To me, the Model Forests are the best vehicle we have in Canada for developing an effective, community-based system of governance and management. They have the success of forming new working partnerships during Phase I, they are generally unencumbered by the baggage that inevitably accompanies an initiative from the province, the forest companies, or special interest groups, and they have developed a familiarity with and understanding of the land base on which they operate. Hopefully each Model Forest now has some sense of what elements should be pursued to achieve sustainable forest management locally.

I believe each Model Forest should strive to form a community-based organization by the end of Phase II - one with clear responsibility and authority for resource management, one which is well on the road to financial independence, and one which is clearly arms-length and independent from government and the forest industry. But for this to happen, the provincial governments and the forest industry across Canada will have to lend their full support. I hope we will see that support.

\section{Incorporation of Ecologically Sound Forest Practices Into Forest Management Planning}

The first two challenges I have presented are admittedly ambitious, and some would say, radical. The third challenge however is less ambitious, and some would say, modest. A universal expectation of the Model Forest Program is "change on the ground." At the end of Phase II, we should see clear evidence that forest management practices, programs and activities are different than they were in 1992. Change on the ground happens through forest operations, and changes in forest operations happen only if they have been incorporated into the five-year forest management plans and the annual work plans.

This is because those plans define specifically what operational activities will be funded and carried out within the plan period. If the new ecologically sound forest practices are not evident in the plans, then it is highly unlikely that they will appear on the ground. The reality is that the forest management plan is the sole vehicle for implementing all operational practices, old and new, within the forest management unit.

This challenge has three components:

1. The knowledge, technology and practices developed through the Model Forest Program should be reviewed for their validity and relevance to the Model Forest area. Presumably the work that has been done should be highly relevant to the Model Forest; otherwise it should not have been funded. If further work is needed for validation, then this should be completed. I see this as the step that will identify and implement local indicators of sustainable forest management.
2. A schedule should be developed for incorporation of the new knowledge and practices into the five-year management plan for the Model Forest area.

3. A plan should be developed for transfer of this knowledge and technology from each Model Forest area to other divisions managed by the industrial partners in the Model Forest.

Through all of this, the Directors of the Model Forests should be deeply involved to ensure that everyone understands the benefits and the costs of incorporating this new knowledge and technology into operational programs.

This third challenge should be considered as an absolute minimum for each Model Forest. If "change on the ground" does not happen by the end of Phase II, the credibility of the Model Forest Program will suffer tremendously, and the public will justifiably become disenchanted and sceptical about the prospect of achieving sustainable forest management in Canada.

\section{Summary}

Canada's forests are a unique asset with many values that have not been appreciated by Canadians. They have enormous unrealized potential. The task ahead is to develop ways of managing our forests to provide revenue, income, employment and community stability within the criteria and indicators for sustainable forest management.

I have left you with three proposals which I believe will help to make sustainable forest management the reality we all desire, both on the ground and in the boardrooms. These proposals provide the mechanism to advance the objectives of Phase II - world class leadership, practical application of sustainable forest management systems, establishing local indicators of sustainable forest management, and incorporating a broad range of values into each Model Forest. Canada's Model Forests are uniquely positioned to show Canada and the world that sustainable forestry can progress from a concept to reality.

\section{References}

Carrow, R. 1996. Establishment of a forest management agency on the Bracebridge Crown management unit. Ont. Min. Natural Resources, Parry Sound Dist. Parry Sound, ON.

Environment Canada. 1995. Canadian biodiversity strategy. Canada's response to the convention on biological diversity. Environment Canada, Ottawa, ON.

Forestry Canada. 1989. 1989 national survey of Canadian public opinion on forestry issues. Forestry Canada, Ottawa, ON.

Rifkin, J. 1995. The end of work. G.P. Putnam's Sons, New York. The Economist. 1991. The future of forests. 22 June 1991.

World Commission on Environment and Development. 1987. Our Common Future. Oxford University Press, Oxford.

\section{Editor's Note}

Westwind Forest Stewardship Inc. The corporation appointed an eight-person Board of Directors from the local community in 1997, with representatives from small business, the financial sector, independent loggers, local forest industry, ecology/wildlife and the public at large. The Board provides strategic direction to the corporation. A Sustainable Forest Licence was issued in May, 1998. At this stage, Westwind is involved primarily in harvest allocation, silviculture, skills training for aboriginal and non-aboriginal workers (e.g., tree marking), 
and active promotion of integrated use of the licence area. Since Westwind is a not-for-profit company it has been eligible to receive funding from the Ivey Foundation, and these funds are being used to promote stewardship on private land by holding conferences and workshops for private landowners.

The Bras d'Or Stewardship Commission. The proposal to form an independent community-based commission has not been implemented by the province, largely because some provin- cial departments oppose the transfer of authority and responsibility to the community. However, the proposal itself has spawned the formation of the Bras d'Or Stewardship Society which incorporated one year ago with a 13-person Board of Directors. The Society's main focus is on public education to promote good stewardship in the Lake Bras d'Or watershed in order to protect the water quality of the lake. The proposal has also led to increased funding to test and monitor water quality in the Bras d'Or Lakes. 